\title{
SPEECH DEVELOPMENT IN HEARING-IMPAIRED CHILDREN OF PRESCHOOL AGE THROUGH THEATRICAL PLAY \\ Maqsud Qodirov ${ }^{1}$ \\ ${ }^{I}$ Teacher of the Department of Deaf Pedagogy, Tashkent State Pedagogical University named after Nizami.
}

\begin{abstract}
This article discusses the content of speech development for hearing-impaired children of preschool age through theatrical play. Theatrical play explores ways to improve the speech development of hearingimpaired preschoolers. The article also discusses the didactic basis for the use of theatrical play activities in the educational process of hearing-impaired children of preschool age. Through theatrical performances, the ways of artistic education and upbringing of children, the formation of aesthetic taste, the development of communicative qualities are revealed.
\end{abstract}

Keywords: Theatrical play, preschool hearing impaired children, speech, development, activity, personality, didactics.

\section{INTRODUCTION}

Theatrical performance in preschool is a new pedagogical concept, and researcher N.A. Vetlugina emphasizes that the aesthetics and art of theatrical performances develop children's creative imagination. L.V. Artemeva, L.V. Voroshnina, L.S. Vigotskiy, R.I. Jukovskaya, N.S. Karpinskaya, A.N. Leontev and other scholars have found that theatrical activity has a significant effect on the development of personality traits such as initiative, imagination, and the ability to identify specific events in events and happenings $[1,87]$. The importance and uniqueness of theatrical performances are related to the perception, perception and impact of the artistic image on the individual.

\section{MAIN PART}

Theater is one of the arts that children can master and helps to solve current problems in pedagogy and psychology $[4,21]$ :

- art education and upbringing of children;

- formation of aesthetic taste;

- moral education;

- development of communicative qualities of the person;

- cultivate the will, develop memory, imagination, initiative, imagination and speech;

- Creating a positive emotional environment, relieving pressure, resolving conflicts through play.

The educational possibilities of theatrical activity are very wide. It allows the child to be creative, to be creative. Children learn to identify interesting ideas in the world around them, to apply them to their artistic images, to create their own artistic images, they develop creative imagination, associative thinking, the ability to see unusual and unique things. Theatrical performances are one of the brightest emotional tools for children's artistic taste. Collective theatrical activity is aimed at the full impact on the child's personality, to support him, to create independently, to develop the leading mental processes, it serves the individual to selfawareness and self-expression, creates conditions for socialization, social adaptation, develops communicative skills, helps to understand the feelings of satisfaction, joy, success $[3,76]$.

Through theatrical performances, preschool children can be educated in moral aesthetics. Theatrical performances are one of the most effective means of engaging preschool children, and through the performance of works of art or folklore, children acquire a number of positive moral and aesthetic qualities.

In theatrical performances, children's emotional development takes place: children get acquainted with the inner experiences and moods of the protagonists, learn to reflect them, understand the causes of this or that mood. Theatrical performances play an important role in speech development (improving dialogic and monologue speech, expressiveness of speech). Theatrical performances are also a means of self-expression and self-expression for the child.

In theatrical performances, hearing-impaired children learn about the world around them, the colors of sounds through images, and the challenges they face teach children to think, reason, analyze, draw conclusions, and generalize. Speech is closely related to mental development. During theatrical performances, the child's vocabulary becomes less active, speech defects are eliminated, pronunciation is improved, and the tone of speech is increased. The role played by children, the speech they utter, puts before the child the need to express it fluently, clearly and clearly. This improves the child's dialogic speech, its grammatical construction $[2,56]$. Theatrical activity is a source of development of the child's emotions and inner feelings. Theatrical performances develop the child's emotional sphere, allowing him to interact with the characters. 
Theatrical performances also serve to shape behavioral social skills, as any pre-school fiction or fairy tale is always in a moral direction. And their favorite characters are role models for children. It is the child's imitation of this favorite character in relation to the image, which has a positive effect on the formation of personality traits. In addition, theatrical activities allow the child to solve many problems directly with the help of a character. It helps to overcome cowardice, lack of self-confidence, and shyness. Collaborative theatrical performances are an antique form of collaboration. It has everyone: children, teachers, mothers, fathers, grandmothers and grandfathers. By playing with adults, children acquire valuable communication skills. Theatrical activities are not part of the organizational system of teaching children in kindergarten. Educators mainly use them in the organization of holiday mornings and to increase the creative activity of children. In everyday life, however, they are organized to do something uninteresting, short, and interesting in a group at will. Some educators do not use theatrical performances at all. However, this type of activity is able to solve a number of educational, speech, social, aesthetic problems, to develop children's cognitive activities. In the development of the field of knowledge:

- Develops perceptions of reality in every way

- Behavior of animals, observation of natural phenomena

- Ensuring the connection between theatrical performances and construction activities promotes the development of spatial imagination, creative activity, intellectual initiative;

- develops memory, rich imagination, teaches to plan their activities to achieve the desired result.

In the field of social development:

- develops positive emotional relationships when working with children;

- fostering cultural awareness in adults and children

- develops communication skills in accordance with the existing ethical laws and regulations in society; - development of senses

In the development of the speech sphere:

- in the development of monologue and dialogic speech

- Vocabulary enrichment: figurative expression, comparison, synonyms, antonyms.

- mastering the means of expression of communication

In the development of the aesthetic field:

- Communication with fiction

- develops forms of imagination based on the description of the artistic image;

- master the design activity in the design of costume elements, decorations, attributes

- to create an expressive artistic image

- Spatial imagination is developed on the basis of project imagination, creative logic, foresight.

- Organization of team work in the creation of multi-figure plot compositions.

- to teach to find independent means of drawing, means.

In the development of the field of movement:

- coordination of actions and accompanying speech.

- to develop the mood, character and image for creative actions

- In sketches, support the main types of movement with musical movement improvisations in expressive performance.

Theatrical activities include:

- Watch puppet shows and talk about them;

- Dramatic games;

- Exercises to develop children's social emotional sphere;

- Correctional games; diction exercises (articulatory gymnastics);

- Assignments to develop speech tone;

- Turning games ("learning to control your body"), figurative exercises;

- Exercises to develop children's plasticity;

- Rhythmic minutes (logarithmics);

- Finger play training to develop hand motor skills needed to control puppets freely;

- Exercises that develop elements of expressive facial expressions, pantomime;

- theatrical studies;

- special cultural exercises during dramatization;

- Preparation (rehearsals) for the performance of various fairy tales and scenes and their performance;

- Get acquainted not only with the text of the fairy tale, but also with the means of dramatizing it gestures, facial expressions, gestures, costumes, scenery, etc.

Speech development tasks of theatrical activity

Middle group.

Enrich and activate children's vocabulary. Learn to identify theatrical characters, objects, scenery, and locations, and to describe the mood and emotional state of theater characters. Strengthen the correct pronunciation of vowels and consonants. Improve the pronunciation of words and phrases. Forming the expressiveness and tone of speech. Developing children's dialogic speech during theatrical performances.

Large group. 
Continue to enrich and activate children's vocabulary, use nouns, adjectives, verbs, forms, numbers, rhymes in speech, and strengthen the correct pronunciation of all sounds. Improving the intonation of speech. Continue to teach children to use direct and indirect speech in storytelling. Development of dialogic and monolithic forms of speech and encouragement. Improving the ability to tell tales in a coherent and expressive way without the help of adults.

Preparatory group.

Activate and continue to clarify children's vocabulary. Expand the vocabulary with the name of the subject, movement, sign. Strengthen the correct pronunciation of all sounds, continue to work on diction and intonation of speech. Improving dialogic and monologic forms of speech. Fostering a culture of verbal communication.

\section{CONCLUSION}

One of the main conditions for successful mastery of theatrical performances by children is the cooperation of parents and educators. Speech development is inextricably linked with the formation of a child's thinking and imagination. The ability to compose simple but interesting stories, grammatically and phonetically correct sentences, which are gradually formed, serves to master the monologue, and at the same time is important for the full preparation of the child for school education. . Also, children's vocabulary gradually expands during the preschool years, but its quality requires the direct participation of adults. Accordingly, it can be concluded that theatrical performances allow the use of a powerful but non-compulsory pedagogical tool in speech development, as the child feels independent and free during play.

\section{REFERENCES}

[1] Petrova T.I. Theatrical games in kindergarten. - M., 2000.204 p.

[2] Ershova A.P. The relationship between the processes of training and education in theatrical education // Aesthetic education. - M., 2002.118 p.

[3] A. V. Shchetkin Theatrical activity in the kindergarten Mosaic - Synthesis, 2008. 16c.

[4] Leonhard E.I., Samsonova E.G. The development of speech in children with hearing impairments in the family. -M., 1991.

[5] Akulova O. Theatrical games // Preschool education, 2005. - №4.

[6] Antipina E.A. Theatrical activities in kindergarten. - M., 2003.

[7] Davydov V.G. From children's games to creative games and dramatizations // Theater and education: Sat. scientific papers. - M. 1992.

[8] Yuldashev M. Synonymic Words in Abdulhamid Sulaymon Cho'lpon's Works. The International journal of analytical and experimental modal analysis. ISSN No:0886-9367. Volume XII, Issue VI, June/2020. Page No: 1732-1739.

[9] Makhaneva M. D. "Theatrical lessons in kindergarten".

[10] Churilova E.G. "Methodology and organization of theatrical activities of preschool children."

[11] Urunova. Z.N. The Role of Modern Pedagogical Technology in the Development of Cognition in Children with Hearing Impairment. International Journal of Progressive Sciences and Technologies (IJPSAT) ISSN: 2509-0119. Vol. 20 No. 2 May 2020, pp. 32-35.

[12] Abdullaeva M.M.The Development of Conditioned Reflex Motor Reactions in Children after Cochlear Implantation. International Journal of Progressive Sciences and Technologies (IJPSAT) ISSN: 2509-0119. Vol. 20 No. 2 May 2020, pp. 01-03

[13] Pulatova S.M. FEATURES OF DIAGNOSING THE LEVEL OF SENSORY DEVELOPMENT OF PRESCHOOL CHILDREN WITH HEARING IMPAIRMENT. European Journal of Research and Reflection in Educational Sciences. Vol. 8 No. 5, 2020. ISSN 2056-5852. pp.18-21.

[14] Irgashevich, D. A. (2020). Development of national network (tas-ix). ACADEMICIA: An International Multidisciplinary Research Journal, 10(5), 144-151. Article http://dx.doi.org/10.5958/2249-7137.2020.00254.2 